\title{
Role of the Liver in Splanchnic Extraction of Atrial Natriuretic Factor in the Rat
}

\author{
Alexander L. Gerbes, ${ }^{1}$ Rochus Witthaut, ${ }^{1}$ Veit Gülberg,,${ }^{1}$ GaÉtan ThIBault, ${ }^{2}$ Manfred BilzeR ${ }^{1}$ AND \\ DIETER JÜNGST ${ }^{1}$ \\ ${ }^{1}$ Department of Medicine II, Klinikum Grosshadern, University of Munich, W-8000 Munich 70, Germany and ${ }^{2}$ Clinical \\ Research Institute, Montreal, Quebec H2W 1R7, Canada
}

\begin{abstract}
Mesenteric, hepatic and splanchnic extraction of C-terminal and $\mathbf{N}$-terminal atrial natriuretic factor was investigated in male Sprague-Dawley rats. Plasma concentrations (mean \pm S.E.M.) of C-terminal atrial natriuretic factor were $55.0 \pm 6.1 \mathrm{fmol} / \mathrm{ml}, 31.2 \pm 4.0$ $\mathrm{fmol} / \mathrm{ml}$ and $23.5 \pm 3.3 \mathrm{fmol} / \mathrm{ml}(\mathrm{n}=12)$ in the $\mathrm{ab}$ dominal aorta, the portal vein and the hepatic vein, respectively. N-terminal atrial natriuretic factor plasma levels in these vessels were $3031 \pm 756 \mathrm{fmol} / \mathrm{ml}$, $2264 \pm 661 \mathrm{fmol} / \mathrm{ml}$ and $1618 \pm 496 \mathrm{fmol} / \mathrm{ml}(\mathrm{n}=6)$, respectively. Although the mesenteric extraction ratio was higher (p $<0.05$ ) for $C$-terminal atrial natriuretic factor $(42 \% \pm 6 \%$ ) than for $N$-terminal atrial natriuretic factor $(28 \% \pm 4 \%)$, there were no significant differences in the hepatic extraction ratio $(41 \% \pm 5 \%$ v8. $39 \% \pm 6 \%$ ) and the splanchnic extraction ratio $(56 \% \pm 5 \%$ v8. $50 \% \pm 7 \%)$. These data suggest a major role of the liver in the splanchnic extraction of $\mathrm{C}$-terminal and of $\mathrm{N}$-terminal atrial natriuretic factor in the rat. (HEPATOLOGY 1992;16:790-793.)
\end{abstract}

The atrial natriuretic factor (ANF) has been shown to be involved in volume homeostasis (1-7). Furthermore, there is increasing evidence that it may play a role in immune and reproductive functions $(8,9)$. ANF circulates as a 28-amino acid C-terminal fragment and a 98-amino acid N-terminal fragment. Although the C-terminal fragment is known to be the bioactive compound of $\mathrm{ANF}$, the biological role of the $\mathrm{N}$-terminal is not yet clearly established. However, there is evidence of a vasodilatory effect of this fragment after further cleavage in plasma (10).

As yet, there is limited knowledge of the clearance of ANF from the circulation because there are only a few studies on the extraction ratios of C-terminal ANF by various organs and there is virtually no information on

Received January 10, 1992; accepted May 1, 1992

This study was supported by the Deutsche Forschungsgemeinschaft (Ge 576/2-2) and by an Asche Stipendium to A. L. Gerbes. This work contains data from a doctoral thesis by R. Witthaut and V. Gülberg at the Ludwig-Maximilians University, Munich, Germany.

Address reprint requests to: Alexander L. Gerbes, M.D., Medizinische Klinik II, Klinikum Grosshadern, Universität München, Marchioninistrasse 15, 8000 Munich 70, Germany

31/1/39355 the clearance of the $\mathrm{N}$-terminal fragment (11). In human beings and dogs, a significant extraction of ANF by the lungs, the kidney, the peripheral circulation and the splanchnic circulation has been shown (12). So far no information exists on the role of the liver in the splanchnic extraction of ANF. Although one study uses ANF infusion (13), no data are available on ANF extraction under basal conditions in the rat (14). However, these may be questions of considerable interest because there is conflicting information on ANF plasma concentrations in liver disease (7, 15-17). Therefore, to characterize the extraction of circulating ANF in more detail, we investigated the role of the liver in extraction of C-terminal and $\mathrm{N}$-terminal ANF in rats.

\section{MATERIALS AND METHODS}

Animals. Male Sprague-Dawley rats weighing $280 \mathrm{gm}$ to $330 \mathrm{gm}$ and kept under standardized conditions were anesthetized with sodium pentobarbital intraperitoneally $(60 \mathrm{mg} / \mathrm{kg})$, heparinized with 250 IU intravenously and then laparotomized. Multiple blood sampling was carried out by direct vessel puncture (abdominal aorta and portal vein) or by venous catheterization with a 20 -gauge Teflon cannula (hepatic vein). Blood was immediately transferred into precooled tubes containing EDTA $(1 \mathrm{mg} / \mathrm{ml})$, centrifuged at $1500 \mathrm{gm}$ and stored at $-70^{\circ} \mathrm{C}$ until assay.

RIA for ANF. C-terminal ANF (99 to 126) was determined in the extract of $100 \mu$ l plasma by use of antibody Toni III (18, 19), as published previously. Intraassay and interassay variations were below $10 \%$ and $15 \%$, respectively; recoveries averaged $70 \%$. The RIA for the $\mathrm{N}$-terminal fragment of pro-ANF was performed with $50 \mu$ l plasma and antibody GT 23 as described elsewhere in detail (20). The intraassay and interassay coefficients of variation were less than $12 \%$, and recoveries were close to $100 \%$.

Calculations and Statistical Evaluation. Extraction ratios in percentages for $\mathrm{C}$-terminal and $\mathrm{N}$-terminal ANF were calculated by the following formulas: Splanchnic extraction $=\left(\left[\mathrm{C}_{\mathrm{a}}-\mathrm{C}_{\mathrm{h}}\right] / \mathrm{C}_{\mathrm{a}}\right) \times 100(\%)$, Mesenteric extraction $=$ $\left(\left[\mathrm{C}_{\mathrm{a}}-\mathrm{C}_{\mathrm{p}}\right] / \mathrm{C}_{\mathrm{a}}\right) \times 100(\%)$ and Hepatic extraction $=\left(\left[2 / 3 \mathrm{C}_{\mathrm{p}}+\right.\right.$ $\left.\left.1 / 3 C_{a}-C_{h}\right] /\left[2 / 3 C_{p}+1 / 3 C_{a}\right]\right) \times 100(\%)$, where $C=$ concentration, $a=$ abdominal aorta, $p=$ portal vein and $h=$ hepatic vein. These formulas are based on the finding that blood flow through the portal vein is twice the hepatic arterial blood flow (21). Concentration gradients in femtomoles per milliliter were calculated accordingly. For these calculations values from 


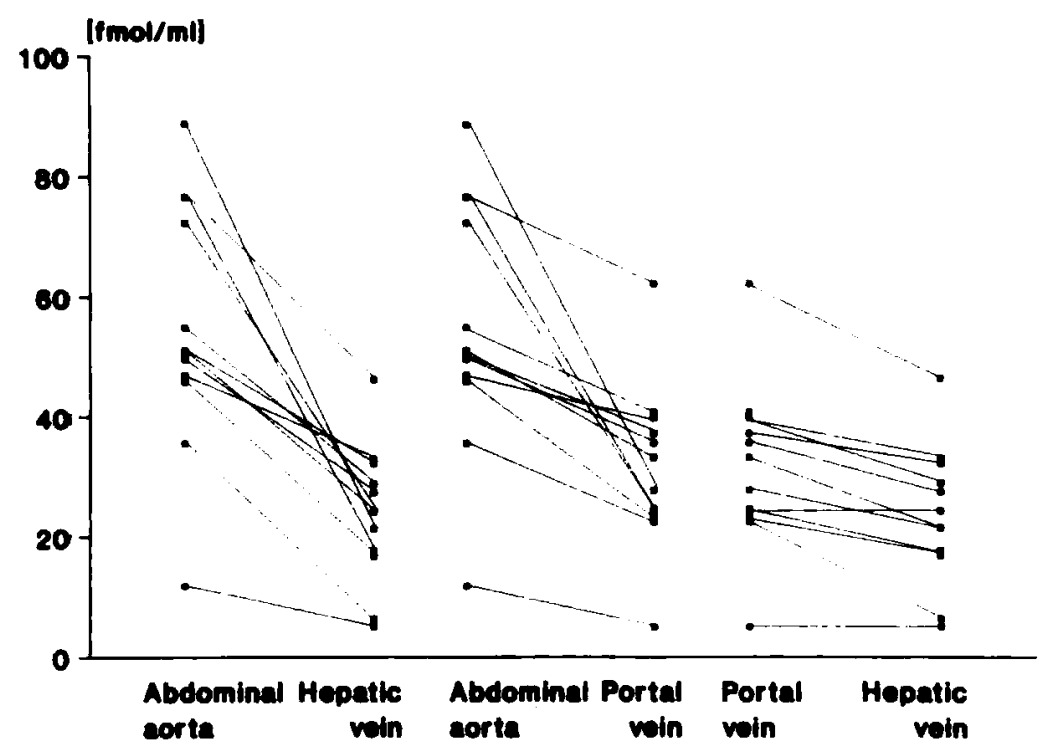

FIG. 1. Plasma concentrations of C-terminal ANF in abdominal aorta, portal vein and hepatic vein of rats. Lines connect the values obtained in the same animals.

different vascular regions of the same animal (paired samples) were used.

Differences between means were compared by paired and unpaired $t$ tests where appropriate. A $\mathrm{p}$ value of less than 0.05 was considered statistically significant. Data are presented as mean and S.E.

\section{RESULTS}

The plasma concentrations of C-terminal ANF in the hepatic vein $(23.5 \pm 3.3 \mathrm{fmol} / \mathrm{ml})$ were significantly lower ( $p<0.001)$ than in the abdominal aorta (55.0 $\pm 6.1 \mathrm{fmol} / \mathrm{ml} ; \mathrm{n}=12$ ) (Fig. 1), corresponding to a splanchnic extraction ratio of $56 \% \pm 5 \%$ (Table 1 ). Mesenteric ANF extraction rate was lower $(42 \% \pm 6 \%)$ (Table 1), with concentrations of C-terminal ANF in the portal vein of $31.2 \pm 4.0 \mathrm{fmol} / \mathrm{ml}$ and in the abdominal aorta of $55.0 \pm 6.1 \mathrm{fmol} / \mathrm{ml}(\mathrm{n}=12 ; \mathrm{p}<0.001)$. Plasma concentrations in the hepatic vein $(23.5 \pm 3.3 \mathrm{fmol} / \mathrm{ml})$ were significantly lower $(\mathrm{p}<0.001)$ than in the portal vein (31.2 $\pm 4.0 \mathrm{fmol} / \mathrm{ml} ; n=12)$ (Fig. 1). Taking into account the arterial part of liver perfusion, we found that $41 \% \pm 5 \%$ of $\mathrm{C}$-terminal ANF was eliminated by the liver. This figure was not significantly different from the mesenteric extraction rate of $42 \% \pm 6 \%$ (Table 1 ).

Splanchnic extraction of $\mathrm{N}$-terminal ANF averaged $50 \% \pm 7 \%$ (Table 1 ), with concentrations of the $\mathrm{N}$-terminal fragment of $3,031 \pm 756 \mathrm{fmol} / \mathrm{ml}$ in the aorta and $1,618 \pm 496 \mathrm{fmol} / \mathrm{ml}$ in the hepatic vein ( $\mathrm{p}<0.005 ; \mathrm{n}=6$ ). Mesenteric extraction of the $\mathrm{N}$-terminal ANF was significantly lower than that of the C-terminal ANF (28\% $\pm 4 \%$ vs. $42 \% \pm 6 \%$; $<0.01$ ), with concentrations of $2,264 \pm 661 \mathrm{fmol} / \mathrm{ml}$ in the portal vein and $3,031 \pm 756 \mathrm{fmol} / \mathrm{ml}$ in the aorta ( $\mathrm{p}<0.001 ; \mathrm{n}=6$ ). The concentration of $\mathrm{N}$-terminal ANF was $1,618 \pm 496 \mathrm{fmol} / \mathrm{ml}$ in the hepatic vein as opposed to $2,264 \pm 661 \mathrm{fmol} / \mathrm{ml}$ in the portal vein $(\mathrm{p}<0.05 ; \mathrm{n}=6$ ) (Fig. 2), resulting in hepatic extrac- tion of $39 \% \pm 6 \%$ (Table 1). Hepatic extraction of $\mathrm{N}$-terminal ANF was significantly higher $(39 \% \pm 6 \%)$ than mesenteric extraction $(28 \% \pm 4 \%$; $<0.05)$.

\section{DISCUSSION}

This study provides new results on the role of the liver in splanchnic ANF extraction and the splanchnic extraction of N-terminal ANF. The splanchnic extraction rate of C-terminal $\mathrm{ANF}$ in rats was found to be $56 \%$. This rate is well in the range reported for the intestinal ANF extraction in human beings $(28 \%$ to $71 \%)(12,17,22-27)$ and somewhat higher than the $28 \%$ to $36 \%$ reported in dogs $(12,28)$. The role of the liver in the splanchnic ANF extraction has not been established so far. However, there is evidence that in liver failure the clearance of ANF is reduced (29). Furthermore, a significant uptake of iodinated ANF from the circulation by the liver suggests a role of this organ in ANF clearance (30). Recently, Hollister et al. (12) observed a concentration difference corresponding to $16 \%$ of C-terminal ANF between portal and hepatic veins in dogs. In view of the much higher concentration of ANF in arterial blood and the fact that hepatic arterial blood flow constitutes about one third of total hepatic blood flow (21), this would indicate a hepatic ANF extraction of about $44 \%$-very close to the $41 \%$ that we found in the rat. In our study the rate of hepatic extraction of C-terminal ANF $(41 \% \pm 5 \%)$ was similar to the mesenteric extraction rate $(42 \% \pm 6 \%)$.

As yet, there are no data available on extraction of the N-terminal ANF fragment. Our data show that $\mathrm{N}$-terminal ANF is extracted in the splanchnic circulation and that the liver is more important in this regard than the mesenteric circulation $(39 \% \pm 6 \%$ vs. $28 \% \pm 4 \%$ extraction; $\mathrm{p}<0.05$ ). Thus although the hepatic extraction ratio of $\mathrm{C}$-terminal and $\mathrm{N}$-terminal 


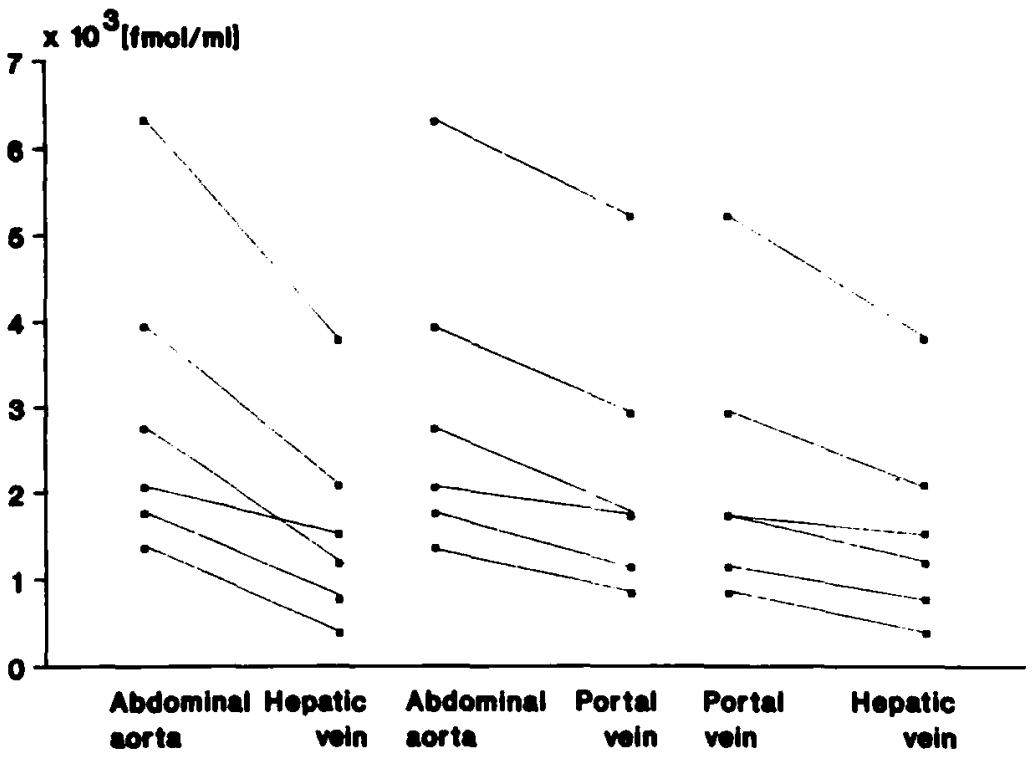

Fig. 2. Plasma concentrations of $\mathrm{N}$-terminal ANF in abdominal aorta, portal vein and hepatic vein of rats. Lines connect the values obtained in the same animals.

TABLE 1. Extraction of ANF in rats

\begin{tabular}{|c|c|c|c|c|}
\hline & \multicolumn{2}{|c|}{ C-termingl ANF ${ }^{a}$} & \multicolumn{2}{|c|}{ N-terminal ANF } \\
\hline & $\begin{array}{l}\text { Concentration } \\
\text { gradient (fmol/ml) }\end{array}$ & Extraction (\%) & $\begin{array}{l}\text { Concentration } \\
\text { gradient (fmol/ml) }\end{array}$ & Extraction (\%) \\
\hline Mesenteric extraction & $23.8 \pm 5.4^{c, d}$ & $41.6 \pm 5.8^{d}$ & $766 \pm 130^{d, e, f}$ & $28.3 \pm 4.1^{d, e, f}$ \\
\hline Hepatic extraction & $15.6 \pm 2.0^{d}$ & $40.8 \pm 4.6^{d}$ & $901 \pm 217^{d, e}$ & $39.1 \pm 6.1^{d}$ \\
\hline Splanchnic extraction & $31.5 \pm 1.9^{f}$ & $56.2 \pm 5.0^{f}$ & $1412 \pm 295^{e, f}$ & $49.9 \pm 6.5^{f}$ \\
\hline
\end{tabular}

${ }^{a} \mathrm{n}=12$

${ }^{b} \mathrm{n}=6$.

'Data expressed as mean \pm S.E.M.

${ }^{d} \mathrm{p}<0.05$ vs. splanchnic extraction.

${ }^{e} p<0.05$ vs. corresponding C-terminal values.

$f_{p}<0.05$ vs. hepatic extraction.

ANF fragments by the liver is similar, the mesenteric extraction of C-terminal ANF is greater than that of the $\mathrm{N}$-terminal fragment. It has been shown that clearance of the C-terminal ANF is caused by three mechanisms. The first mechanism is the binding of ANF to the C-receptor, subsequent internalization and rapid degradation in lysosomes. The second is the enzymatic degradation by endopeptidase 24.11 (11) and by a carboxypeptidase $(31,32)$. The third mechanism, which is rather unspecific, is glomerular filtration and renal excretion. Endopeptidase 24.11 activity has been demonstrated mainly in the kidney, but recently also in the mesentric artery of the rat by ex vivo perfusion and membrane preparation techniques (33). Presence of the C-receptor has been shown in various organs including the liver (34). There are no data as yet on the mechanisms of clearance of the $\mathrm{N}$-terminal ANF fragment. Altogether our data suggest a major role of the liver in the splanchnic extraction of C-terminal and $\mathrm{N}$-terminal ANF in the rat.
Acknowledgments: We thank Dr. R. M. Arendt for providing antibody Toni III, A. Benner and J. Bilodeau for providing technical assistance and F. Ringel and J. Nagl for preparing the manuscript.

\section{REFERENCES}

1. De Bold AJ. Atrial natriuretic factor: an overview. Fed Proc 1986;45:2081-2085.

2. Inagami T. Atrial natriuretic factor. J Biol Chem 1989;264:30433046.

3. Lang RE, Unger T, Ganten D. Atrial natriuretic peptide: a new factor in blood pressure control. J Hypertens 1987;5:255-271.

4. Laragh JH, Atlas SA. Atrial natriuretic hormone: a regulator of blood pressure and volume homeostasis. Kidney Int 1988;34: 64-71.

5. Needleman PJ, Greenwald JE. Atriopeptin: a cardiac hormone intimately involved in fluid, electrolyte, and blood-pressure homeostasis. N Engl J Med 1986;314:828-834.

6. Thibault G, Garcia R, Gutkowska J, Genest J, Cantin M. Atrial natriuretic factor. A newly discovered hormone with significant clinical implications. Drugs 1986;31:369-375.

7. Gerbes AL, Arendt RM, Paumgartner G. Atrial natriuretic factor: possible implications in liver disease. J Hepatol 1987;5:123-132. 
8. Gutkowska J, Nemer M. Structure, expression and function of atrial natriuretic factor in extraatrial tissues. Endocr Rev 1989; 10:519-536.

9. Vollmar AM. Atrial natriuretic peptide in peripheral organs other than the heart. Klin Wochenschr 1990;68:699-704.

10. Veseley DL, Norris JS, Walters JM, Jespersen RR, Baeyens DA. Atrial natriuretic pro-hormone peptides 1-30, 31-67, and 79-98 vasodilate the aorta. Biochem Biophys Res Commun 1990;148: $1540-1548$.

11. Gerbes AL, Vollmar AM. Degradation and clearance of atrial natriuretic factors (ANF). Life Sci 1990;47:1173-1180.

12. Hollister AS, Rodeheffer RJ, White FJ, Potts JR, Imada ER Inagami $T$. Clearance of atrial natriuretic factor by lung, liver and kidney in human subjects and the dog. $J$ Clin Invest 1989;83: 623-628.

13. Krieter PA, Trapani AJ. Metabolism of atrial natriuretic peptide. Extractions by organs in the rat. Drug Metab Dispos 1989;17: 14-19.

14. Gerbes AL, Vollmar AM. Processing and clearance of atrial natriuretic factor (ANF). In: Henriksen JH, ed. Degradation of bioactive substances: physiology and pathophysiology. Boca Raton: CRC Press, 1991:129-141.

15. Gerbes AL, Arendt RM, Stangl E, Gülberg V, Sauerbruch T, Jüngst $D$, Paumgartner $G$. Characterization of the ANF system in patients with cirrhosis of the liver. In: Forssmann WG, Scheuermann DW, Alt J, eds. Functional morphology of the endocrine heart. Darmstadt: Steinkopff, 1989:229-234.

16. Epstein M, Loutzenheiser R, Norsk P, Atlas S. Relationship between plasma ANF responsiveness and renal sodium handling in cirrhotic humans. Am J Nephrol 1989;9:133-143.

17. Henriksen JH, Schütten HJ, Bendtsen F, Warberg J. Circulating atrial natriuretic peptide (ANP) and central blood volume (CBV) in cirrhosis. Liver 1986;6:361-368

18. Arendt RM, Gerbes AL, Ritter D, Stangl E. Molecular weight heterogeneity of plasma ANF in cardiovascular disease. Klin Wochenschr 1986;64(suppl 4):97-102.

19. Gerbes AL, Wernze $H$, Arendt RM, Riedel A, Sauerbruch T, Paumgartner G. Atrial natriuretic factor and renin-aldosterone in volume regulation of patients with cirrhosis. HePATOLOGY 1989; 9:417-422

20. Sundsfjord JA, Thibault G, Larochelle P, Cantin M. Identification and plasma concentrations of the $\mathrm{N}$-terminal fragment of proatrial natriuretic factor in man. J Clin Endocrinol Metab 1988;66: $605-610$

21. Casado J, Fernández-López JA, Esteve M, Rafecas I, Argilés JM,
Alemany M. Rat splanchnic net oxygen consumption, energy implications. J Physiol (Lond) 1990;431:557-569.

22. Crozier IG, Nicholls MG, Ikram H, Espiner EA, Yandle TG, Jan $S$. Atrial natriuretic peptide in humans. Production and clearance by various tissues. Hypertension 1986;8(suppl 2):11-15.

23. Schütten HJ, Henriksen JH, Warberg J. Organ extraction of atrial natriuretic peptide (ANP) in man. Significance of sampling site Clin Physiol 1987;7:125-132.

24. Gines P, Jimenez W, Arroyo V, Navasa M, Lopez C, Tito L, Serra $A$, et al. Atrial natriuretic factor in cirrhosis with ascites: plasma levels, cardiac release and splanchnic extraction. HEPATOLOGY 1988;8:636-642.

25. Vierhapper H, Gasic S, Nowotny $P$, Waldhäusl W. Splanchnic disposal of atrial natriuretic peptide in humans. Metabolism 1988;37:973-975.

26. Kurusawa T, Hiramatsu S, Katoh Y, Kikawada R, Marumo F. No specific organ removes atrial natriuretic peptide from the human plasma. Jpn Circ J 1989;53:779-785.

27. Henriksen JH, Bendtsen F, Gerbes AL. Splanchnic removal of human alpha atrial natriuretic peptide (human ANP 99-126) in man: enhancement after food intake. Metabolism 1990;39: 553-556.

28. Masuda T, Shichiri M, Marumo F. Degradation of atrial natriuretic peptide in dogs. Acta Endocrinol 1989;120:170-174.

29. Moreau R, Pussard E, Brenard R, Gaudin C, Berdeaux A, Lebrec D. Clearance of atrial natriuretic peptide in patients with cirrhosis. Role of liver failure. J Hepatol 1991;13:351-357.

30. Widimsky J, Debinsky W, Kuchel O, Buu NT. ANF disappearance and tissue distribution in rats. Am J Physiol 1990;258:H134H139.

31. Johnson GB, Leyla A, Foster CJ. Metabolism of ${ }^{125}$ I-atrial natriuretic factor by vascular smooth muscle cells. J Biol Chem 1989;264:11637-11642.

32. Krieter PA, Olins GM, Verrett SP, Durley RC. In vivo metabolism of atrial natriuretic peptide: identification of plasma metabolites and enzymes responsible for their generation. J Pharmacol Exp Ther 1989;249:411-417.

33. Tamburini PP, Koehn JA, Gilligan JP, Charles D, Palmesino RS, McMartin C, Erion MD, et al. Rat vascular tissue contains a neutral endopeptidase capable of degrading atrial natriuretic peptide. J Pharmacol Exp Ther 1989;251:956-961.

34. Nair BG, Seinke L, Yu YM, Rashed HM, Seyer JM, Patel TB Increase in the number of atrial natriuretic hormone receptors in regenerating rat liver. J Biol Chem 1991;266:567-573. 